\title{
PERBANDINGAN TEPUNG SORGUM (Sorghum bicolor L. Moench) DENGAN TEPUNG SINGKONG (Manihot Escolenta) \\ DAN KONSENTRASI GLISEROL MONOSTEARAT (GMS) TERHADAP KARAKTERISTIK BERAS ANALOG FORTIFIKASI
}

\author{
COMPARISON OF SORGUM FLOUR (Sorghum bicolor L. \\ Moench) WITH CASSAVA FLOUR (Manihot Escolenta) AND \\ CONCENTRATION OF GLYCEROL MONOSTEARATE (GMS) \\ ON CHARACTERISTICS OF ANALOG RICE FORTIFICATION
}

\author{
Irfan Hadiyan, Wisnu Cahyadi dan Ina Siti Nurminabari \\ Program Studi Teknologi Pangan, Fakultas Teknik, \\ Universitas Pasundan, Jl. Dr.Setiabudi No 93, Bandung, 40153, Indonesia \\ E-mail : irfanhadiyan@gmail.com
}

\begin{abstract}
ABSTRAK
Latar belakang dalam penelitian ini adalah untuk memanfaatkan komoditi bahan pangan lokal sebagai upaya diversifikasi pangan dan untuk menanggulangi kekurangan akan zat gizi mikro. Tujuan dari penelitian ini adalah mendapatkan formulasi beras analog terbaik dengan menggunakan teknologi ekstruksi yang dapat diterima konsumen secara sensori. Secara spesifik penelitian ini bertujuan untuk mengetahui pengaruh dari konsentrasi tepung sorgum merah dan tepung singkong dan konsentrasi gliserol monostearat terhadap beras analog yang difortifikasi. Manfaat dari penelitian ini adalah memberikan informasi mengenai pembuatan beras analog yang berbasis dari tanaman sorgum dan singkong yang dapat menjadi alternatif makanan pokok dan meningkatkan nilai tambah bahan pangan lokal. Penelitian ini terdiri atas dua tahap yaitu penelitian pendahuluan sebagai yang ditujukan untuk menganalisis secara kimia terhadap bahan baku meliputi kadar air, karbohidrat, lemak, dan protein. Metode penelitian yang digunakan adalah Rancangan Acak Kelompok (RAK) yang meliputi dua faktor yaitu perbandingan tepung sorgum merah dan tepung sigkong, faktor kedua adalah variasi konsentrasi gliserol monostearat (GMS) Kemudian tahap yang kedua yaitu penelitian utama yang dilakukan meliputi rancangan respon organoleptik, penentuan sampel terpilih, dan analisis yang teridiri dari analisis secara kimia meliputi kadar air, abu, protein, lemak, karbohidrat, serat, amilosa, amilopektin, zat besi, dan iodium, kemudian analisis secara mikrobiologis meliputi angka lempeng total dan analisis e.coli, kemudian analisis secara fisik meliputi pengukuran dimensi, bobot 1000 butir, dan densitas kamba.
\end{abstract}

\section{ABSTRACT}

The background in this research is to utilize local food ingredients as an effort to diversify food and to overcome the lack of micronutrients. The purpose of this study is to get the best analog rice formulation using an extrusion technology that can be accepted sensoryly by consumers. Specifically, this study aims to determine the effect of the concentration of red sorghum flour and cassava flour and the concentration of glycerol monostearate on fortified analog rice. The benefit of this study is to provide information on the manufacture of analog rice based on sorghum and cassava plants which can be an alternative staple food and increase the 107 | Jurnal Agriekstensia Vol. 17 No. 2 Desember 2018 
added value of local food ingredients. This researched consists of two stages: preliminary researched as intended to analyzed chemically the raw materials included water, carbohydrate, fat, and protein. The researched method used was a randomized block designed (RBD) which included two factors, namely the ratio of red sorghum flour and cassava flour, the second factor was the variation in the concentration of glycerol monostearate (GMS)., and the analysis consisting of chemical analysis includes water, ash, protein, fat, carbohydrate, fiber, amylose, amylopectin, iron and iodine content, then microbiological analysis included total plate number and e.coli analysis, then analysis physical includes dimensions measurement, 1000 grain weight, and bulk density.

Keywords: Red sorghum flour, cassava flour, glycerol monostearat, analog rice

\section{PENDAHULUAN}

Kekurangan akan zat gizi mikro esensial secara luas menimpa lebih dari sepertiga penduduk dunia, terutama di negara-negara berkembang seperti Indonesia. Ada beberapa masalah defisiensi zat gizi mikro utama di Indonesia yaitu gangguan akibat kekurangan iodium (GAKI), anemia gizi besi (AGB) / kekurangan zat besi, kekurangan asam folat (vitamin B9) dan kekurangan vitamin A (KVA). Kekurangan zat gizi mikro esensial mengakibatkan ketidakmampuan belajar yang baik, keterlambatan mental (gangguan pertumbuhan fisik dan mental), kesehatan yang buruk, kapasitas kerja yang rendah, kebutaan, gondok, dan kehilangan potensi sosial ekonomi dari masyarakat.

Indonesia memiliki berbagai macam sumber bahan pangan hayati terutama yang berbasis karbohidrat. Setiap daerah di Indonesia memiliki karakteristik bahan pangan lokal yang sangat berbeda dengan daerah lainnya. Diversifikasi pangan juga merupakan solusi untuk mengatasi ketergantungan masyarakat Indonesia terhadap satu jenis bahan pangan yakni beras. Selanjutnya ialah mendukung secara nyata kegiatan peningkatan pendapatan in situ (incme generating activity in situ). Peningkatan pendapatan in situ bertujuan meningkatkan pendapatan masyarakat melalui kegiatan pertanian barbasis sumber daya lokal. Dari berbagai aspek permasalahan di atas, sebenarnya ada beberapa solusi yang dapat dilakukan oleh bangsa kita agar memiliki ketahan pangan yang baik. Diantara 108 | Jurnal Agriekstensia Vol. 17 No. 2 Desember 2018 solusi tersebut ialah diversifikasi pangan melalui pengembangan produk pangan fortifikasi zat gizi mikro berbasis kearifan lokal (pangan/sumber daya lokal).

Ketergantungan terhadap beras menjadi masalah disebabkan oleh tingkat konsumsi beras yang sangat tinggi namun tidak diimbangi dengan peningkatan produksi padi. Meskipun masyarakat di beberapa daerah di Indonesia masih ada yang mengonsumsi jagung atau sagu, konsumsi rata-rata beras masyarakat Indonesia masih mencapai angka $120.02 \mathrm{~kg}$ per kapita per tahun pada tahun 2007 (Muttaqin dan Martianto 2009). Tingginya tingkat konsumsi di Indonesia selain disebabkan oleh jumlah penduduk yang terus meningkat juga disebabkan oleh pola konsumsi masyarakat yang sulit berubah dari beras ke bahan pangan lain.

Salah satu produk olahan sumber karbohidrat non padi yang dikembangkan akhir-akhir ini adalah beras tiruan dan beras analog. Beras tiruan adalah beras yang dibuat dari non padi dengan kandungan karbohidrat mendekati atau melebihi beras yang terbuat dari tepung lokal atau tepung beras (Samad 2003; Deptan 2011). Beras analog adalah beras tiruan yang hanya terbuat dari tepung lokal non-beras (Budijanto et al. 2011). Hingga saat ini teknologi pembuatan beras analog antara lain metode pembutiran atau granulasi (Yoshida et al. 1971; Kurachi 1995; Samad 2003) dan metode ekstrusi (Scella et al. 1987; Bett-Gaber et al. 2004; Moretti et al. 2005; Mishra et al. 2012). Perbedaan metode tersebut menyebabkan perbedaan bentuk akhir produk. Pada pembuatan beras analog 
menggunakan metode pembutiran beras akan memiliki bentuk bulat seperti sagu mutiara, namun pada metode ekstrusi bentuk produk adalah lonjong dan hampir menyerupai butir beras.

Pemanfaatan sumber karbohidrat non padi seperti jagung, sorgum, singkong, umbi, dan sagu sebagai alternatif makanan pokok memerlukan teknologi yang sesuai dan memiliki kapasitas produksi yang tinggi.

Tanaman singkong merupakan produk hasil pertanian pangan kedua terbesar setelah padi, sehingga ketersediaan singkong mempunyai potensi sebagai bahan baku yang penting dalam berbagai makanan karena memiliki kandungan gizi yang cukup lengkap tetapi pemanfaatan dan diversifikasi tanaman singkong masih sangat kurang. Begitu pula halnya dengan tanaman sorgum yang memiliki kandungan protein dan antioksidan yang tinggi tetapi pemanfaatan dan pengolahan lanjut terhadap tanaman ini masih sangat kurang. Oleh karena itu, pada penelitian ini dilakukan pembuatan beras analog berbahan dasar sorgum dan singkong kemudian difortifikasi oleh zat besi dan iodium dengan menggunakan teknologi ekstrusi. Produk beras analog ini juga diharapkan dapat menjadi produk yang diterima oleh konsumen dan dapat membantu upaya diversifikasi makanan pokok di Indonesia.

\section{METODE PENELITIAN}

Bahan-bahan utama yang akan digunakan pada penelitian pembuatan beras analog fortifikasi adalah tepung sorgum merah, tepung singkong, parutan kelapa, tapioka, Fe-fumarat, Kalium Iodat (KIO3), dan air. Sedangkan bahan yang digunakan untuk analisis kimia adalah $\mathrm{Na} 2 \mathrm{SO} 4$ anhidrat, $\mathrm{HgO}$, selenium black, $\mathrm{H} 2 \mathrm{SO} 4$ pekat, aquadest, $\mathrm{NaOH} 30 \%$, Na2S2O3 $5 \%$, granul $\mathrm{Zn}, \mathrm{HCl} 0.1 \mathrm{~N}$, fenolpthalein, $\mathrm{NaOH} 0.1 \mathrm{~N}$, $\mathrm{HCl} 8 \mathrm{~N}, \mathrm{AgNO} 3$, pelarut n-heksana, H3PO4 pekat, kristal KI, amylum 1\%, Na2S2O3 $0.05 \mathrm{~N}$, air steril, media padat GYEA, Brilliant Green Lactose Bile (BGLB) $2 \%$
Broth, Lauryl Tryptose Broth (LTB), EC Broth, Gliserol Monostearat (GMS) 40.

Alat-alat yang digunakan dalam penelitian ini adalah baskom, pisau, wadah plastik, gelas kimia, gelas ukur, timbangan digital, botol semprot, batang pengaduk, sendok, tray dryer, extruder. Sedangkan alat yang digunakan untuk analisis kimia adalah labu kjedahl, batu didih, labu takar $100 \mathrm{ml}$, pipet, labu Erlenmeyer, destilator, lakmus merah, buret, gelas kimia 500ml, kaca arloji, kertas saring bebas lemak, timbal ekstraksi, oven, penjepit cawan, desikator, timbangan digital, soxhlet, penangas air, desikator, cawan, cawan porselen, pemanas destruksi, tanur listrik, Whatmann No.1, kuvet, Atomic Absorption Spectrofotometry (AAS), grinder, pipet ukur, tabung reaksi, cawan petri, inkubator, waterbath bertutup dengan sirkulasi $45 \mathrm{oC}+0,5 \mathrm{oC}$, inkubator $35 \mathrm{oC} \pm$ $1 \mathrm{oC}$, blender beserta jar yang dapat disterilisasi atau stomacher, botol pengencer, tabung durham, cawan petri ukuran $15 \mathrm{~mm} \times$ $90 \mathrm{~mm}$, tabung reaksi ukuran $16 \mathrm{~mm} \times 150$ $\mathrm{mm}$ dan $13 \mathrm{~mm} \times 100 \mathrm{~mm}$, timbangan dengan ketelitian 0,0001 g, mikroskop, pipet $1 \mathrm{ml}, 5 \mathrm{ml}$ dan $10 \mathrm{ml}$.

Penelitian ini terdiri dari dua tahap, yaitu penelitian pendahuluan dan penelitian utama. Penelitian pendahuluan dilakukan untuk persiapan bahan utama beras analog yaitu penyiapan tepung sorgum merah. Kemudian dilakukan uji proksimat pada bahan baku utama yaitu tepung sorgum merah dan singkong.

Rancangan perlakuan yang digunakan adalah golongan berfaktor yang terdiri dari dua faktor dengan kombinasi perlakuan yang dilaksanakan sebanyak 9 perlakuan, dengan 3 kali ulangan, sehingga jumlahnya 27 satuan percobaan.

Respon pada penelitian utama meliputi respon organoleptik denganatribut warna, tekstur, dan kenampakan. Respon kimia meliputi penentuan kadar air dengan metode gravimetri, penentuan kadar protein dengan metode kjedahl, penentuan kadar abu dengan metode gravimetri, penentuan kadar lemak dengan metode soxhlet, penentuan kadar serat kasar, penentuan kadar 
karbohidrat (gula total) dengan metode Luff Schrool, penentuan kadar Fe dengan metode AAS, penentuan kadar iodium dengan metode spektrofotometri, analisis kadar amilosa dan amilopektin. Respon mikrobiologi meliputi penetian jumlah lempeng total dan kadar e.coli. Respon fisik meliputi pengukuran dimensi, penentuan bobot 1000 butir, dan penentuan densitas kamba.

\section{HASIL DAN PEMBAHASAN}

\section{Hasil Penelitian Pendahuluan}

Analisis kimia yang dilakukan terhadap beras analog meliputi kadar air, lemak, protein, dan karbohidrat dilakukan karena komponen-komponen tersebut merupakan komponen penyusun dalam tepung yang paling besar dan dapat dijadikan sebagai pertimbangan dan perbandingan untuk penelitian utama.

Tabel 1. Hasil Penelitian Pendahuluan.

\begin{tabular}{|c|c|c|}
\hline \multirow{2}{*}{ Komponen } & \multicolumn{2}{|c|}{ Kadar \% b/b } \\
\cline { 2 - 3 } & $\begin{array}{c}\text { Tepung } \\
\text { Sorgum Merah }\end{array}$ & $\begin{array}{c}\text { Tepung } \\
\text { Singkong }\end{array}$ \\
\hline Air & 10.3 & 14.5 \\
\hline Lemak & 0.5 & 0.7 \\
\hline Protein & 10.2 & 1.5 \\
\hline Karbohidrat/ pati & 70.91 & 81.3 \\
\hline
\end{tabular}

Berdasarkan hasil analisis terhadap kadar air tepung sorgum dan tepung singkong memiliki perbedaan dalam tingkat persentasenya, kadar air dalam tepug sorgum merah lebih rendah karena memiliki daya serap air yang lebih kecil disbanding dengan tepung singkong hal tersebut diakibatkan karena pada proses pembuatan tepung sorgum terdapat beberapa bagian yang sukar dihancurkan meskipun dengan ukuran ayakan yang sama bagian tersebut merupakan butiran tepung yang memliki senyawa tanin. Sedangkan pada tepung singkong memiliki ukurang butiran tepung yang relatif sama dan memiliki tekstur yang lebih halus, sehingga hal tersebut berpengaruh terhadap daya serap airnya yang lebih besar daripada tepung sorgum merah.

110 | Jurnal Agriekstensia Vol. 17 No. 2 Desember 2018
Kadar lemak pada kedua bahan memiliki persentase yang berbeda hal, apabila pada tepung sorgum merah $0.5 \%$ sedangkan pada tepung singkong $0.7 \%$. Perbedaan tersebut karena karakteristik sorgum yang merupakan serealia yang kandungan lemaknya rendah karena sebagian besar kandungan lemak hanya berada pada lembaga dan aleuron (Pratiwi, 2011). Sedangkan singkong yang termasuk kedalam umbi-umbian memiliki sejumlah kandungan nutrisi yang dibutuhkan oleh tubuh termasuk salah satunya kadar lemak yang lebih tinggi dari serealia.

Kadar protein yang terdapat pada tepung sorgum merah lebih tinggi dari tepung singkong. Pada biji sorgum sorgum protein dapat dibagi menjadi dua golongan, yaitu protein yang terdapat dalm lembaga dan protein yang tersimpan pada endosperm. Kandungan asam amino seperti lisin, triptofan, dan treonin terdapat pada sebagian besar biji sorgum. Pada tanaman singkong yang merupakan umbi memiliki kandungan asam amino yang lebih lengkap, tetapi ada beberapa jenis asam amino yang tinggi sebagai ciri khas dari singkong yaitu lisin dan treonin.

Dengan proses penepungan, kandungan protein dan nutrisi yang lainnya mengalami penurunan. Kandungan tannin pada biji sorgum turun dan pada singkong pun akan mengalami penurunan kadar protein. Tepung yang diperoleh dengan metode kering mengahasilkan tannin berkadar rendah. Dengan metode basah, kandungan tannin tidak terukur (Winarno, 1997).

Bedasarkan hasil analisis kadar karbohidrat pati menunjukan kedua sampel memiliki persentase yang mendominasi, karena kedua bahan baku yaitu sorgum dan singkong merupakan jenis komoditi bahan makanan pokok yang tinggi akan karbohidrat (pati).

Perbedaan persentase karbohidrat pati dikarenakan perbedaan komoditi, pada singkong memiliki kadar pati yang tinggi, pati yang tersusun atas amilosa dan amilopektin, dimana amilosa bersifat larut dalam air, sedangkan amilopektin tidak larut 
Perbandingan Tepung Sorgum dengan Tepung Singkong .. (Irfan Hadiyan, Wisnu Cahyadi dan Ina Siti Nurminabari)

air. Sehingga pada komoditi dengan kandungan karbohidrat pati yang tinggi akan memliki tekstur yang padat dan kenyal setelah diolah.

\section{Hasil Penelitian Utama}

\section{Respon Organoleptik}

\section{Warna}

Berdasarkan tabel 2, hasil pengolahan data pengujian organoleptik menunjukkan bahwa nilai yang terbesar diberikan oleh panelis adalah 4,14 untuk sampel x2y3 dan paling rendah 2,55 untuk sampel x1y1 yang menunjukkan sampel yang paling tidak di sukai oleh panelis, hal tersebut dikarenakan perbandingan tepung singkong yang relatif sedang dengan konsentrasi GMS terbesar sehingga mempengaruhi warna dan penampilan karena GMS berperan juga sebagai coating pada beras yang memberikan efek mengkilap. Pada proses ekstruksi pada pembuatan beras analog berperan penting proses ekstruksi yang digunakan termasuk metode Hot Extrusion dimana bahan diproses pada suhu di atas $70^{\circ} \mathrm{C}$ sehingga menyebabkan pencampuran dan pemanasan adonan yang efektif serta memberikan warna yang menarik.

Tabel 2. Interaksi Antara Perbandingan Jenis

Tepung dan Konsentrasi GMS Terhadap Warna Beras Analog

\begin{tabular}{|c|c|c|c|}
\hline \multirow{2}{*}{$\begin{array}{l}\text { Perbandingan } \\
\text { Tepung } \\
\text { Sorgum \& } \\
\text { Singkong }\end{array}$} & \multicolumn{3}{|c|}{ Konsentrasi GMS } \\
\hline & y1 $(0.6 \%)$ & y2 $(0.8 \%)$ & y3 (1\%) \\
\hline $\begin{array}{c}x 1 \\
(1: 8)\end{array}$ & $2.55^{\mathrm{A}}$ & $\mathrm{a} \quad{ }^{\mathrm{B}}$ & $\begin{array}{ll} & \mathrm{B} \\
\mathrm{ab} & \\
\end{array}$ \\
\hline $\begin{array}{c}x 2 \\
(1: 6)\end{array}$ & b $3.92^{\mathrm{A}}$ & $\mathrm{a} 3.63^{\mathrm{A}}$ & $\begin{array}{l}\text { A } \\
\text { b } 4.14^{-1}\end{array}$ \\
\hline $\begin{array}{c}x 3 \\
(1: 5)\end{array}$ & b $3.70^{\mathrm{A}}$ & $\mathrm{a} \quad 3.75^{\mathrm{A}}$ & $\begin{array}{ll} & \mathrm{A} \\
\mathrm{a} & \\
\end{array}$ \\
\hline
\end{tabular}

Keterangan : Setiap huruf yang berbeda menunjukan perbedaan yang nyata pada taraf $5 \%$. Huruf kapital dibaca horizontal dan huruf kecil dibaca vertikal

Pada proses ekstruksi panas khususnya pada sampel yang pertama masuk warna produk akan mengalami perubahan warna yang lebih signifikan. Proses ekstruksi awal merupakan proses pre-heating dimana suhu pemanas dan barrel ekstruder selalu berubah-ubah yang menyebabkan suhu sangat tidak konstan pada pemasukan bahan awal, sehingga berakibat pada warna bahan yang tidak seragam.

\section{Tekstur}

Berdasarkan tabel 3 hasil pengolahan data pengujian organoleptik terhadap tekstur menunjukkan bahwa nilai terbesar yang diberikan panelis yaitu 3,78 untuk sampel yang paling disukai dan nilai 2,76 untuk sampel yang rata-rata tidak disukai panelis, sampel yang paling disukai yaitu sampel $\mathrm{x} 2 \mathrm{y} 3$ dengan konsentrasi tepung singkong yang relatif sedang dan konsentrasi GMS $1 \%$.

Tabel 3. Interaksi Antara Perbandingan Jenis

Tepung dan Konsentrasi GMS Terhadap Tekstur Beras Analog.

\begin{tabular}{|c|c|c|c|}
\hline \multirow{2}{*}{$\begin{array}{l}\text { Perbandingan } \\
\text { Tepung } \\
\text { Sorgum \& } \\
\text { Singkong }\end{array}$} & \multicolumn{3}{|c|}{ Konsentrasi GMS } \\
\hline & y1 $(0.6 \%)$ & y2 $(0.8 \%)$ & y3 (1\%) \\
\hline $\begin{array}{c}\text { x1 } \\
(1: 8)\end{array}$ & $2.76^{\mathrm{A}}$ & $\mathrm{a}{ }^{\mathrm{B}}$ & $\begin{array}{l}\text { B } \\
\\
\end{array}$ \\
\hline $\begin{array}{c}x 2 \\
(1: 6)\end{array}$ & b $3.54^{\mathrm{A}}$ & $a 3.40^{\mathrm{A}}$ & $\begin{array}{r}\text { B } \\
\text { b } 3.78^{-} \\
\end{array}$ \\
\hline $\begin{array}{c}\text { x3 } \\
(1: 5)\end{array}$ & $b^{\mathrm{A}}$ & $b^{3.86^{\mathrm{B}}}$ & $b{ }^{\mathrm{A}}$ \\
\hline
\end{tabular}

Keterangan : Setiap huruf yang berbeda menunjukan perbedaan yang nyata pada taraf 5\%. Huruf kapital dibaca horizontal dan huruf kecil dibaca vertikal

Tekstur terbentuk akibat interaksi elemen-elemen struktural dari bahan pangan dan dirasakan, terutama melalui sentuhan, berkaitan dengan deformasi, disintegrasi (pecah) dan aliran bahan ketika bahan diberi gaya. Tekstur diukur secara objektif sebagai fungsi dari massa, waktu dan panjang. Pengkajian tentang tekstur berkaitan dengan struktur (makroskopik, mikroskopik dan molecular) dan perilaku ketika struktur 
Perbandingan Tepung Sorgum dengan Tepung Singkong .. (Irfan Hadiyan, Wisnu Cahyadi dan Ina Siti Nurminabari)

bereaksi akibat diberikan gaya. Tekstur bersifat multidimensional yang terdiri dari sejumlah sifat sensoris. Struktur bahan berkaitan dengan keteraturan dan interaksi antar komponen dalam bahan, serta keteraturan dan interaksinya dibawah pengaruh gaya eksternal dan internal. Struktur juga sering berkaitan dengan bentuk dan ukuran dari komponen-kompponen dalam bahan pangan. Dengan demikian, sifat tekstur dapat diketahui dari deformasi (perubahan bentuk) yang terjadi setelah diberikan tekanan, pemanasan, pembekuan, pencairan (thawing) atau perubahan jaringan pada proses pemasakan buah-buahan. Tekstur merupakan kualitas produk yang paling penting. Produk pangan mempunyai tekstur yang berbeda-beda. Perbedaan tersebut disebabkan oleh perbedaan berbagai faktor seperti tingkat kematangan dan metode pengolahan. Tekstur pangan dapat diukur dengan menggunakan analisis sensoris dan instrumentasi. Analisis sensori dilakukan dengan menggunakan panelis terlatih. Kelemahannya adalah presisi hasil analisis sangat tergantung kualitas dan intensitas pelatihan panelis.

\section{Kenampakan}

Berdasarkan tabel 4 hasil pengolahan data hasil uji organoleptik terhadap tekstur menunjukkan sampel dengan nilai 4,15 merupakan sampel yang rata-rata disukai oleh panelis dan nilai 2,43 merupakan sampel yang paling tidak disukai oleh panelis. Sampel yang paling disukai memiliki konsentrasi tepung singkong yang sedang dang konsentrasi GMS yang tinggi sehingga memberikan kenampakan yang menarik bagi panelis.

Pada sampel beras analog memiliki keragaman kenampakan dan tidak seragam antara satu sampel dengan sampel yang lainnya, karena dari setiap sampel memiliki formulasi bahan yang berbeda. Dari setiap bahan yang digunakan memiliki karakteristik tersendiri yang menyebabkan penampilan beras analog menjadi beragam.
Tabel 4. Interaksi Antara Perbandingan Jenis Tepung dan Konsentrasi GMS Terhadap Kenampakan Beras Analog.

\begin{tabular}{|c|c|c|c|}
\hline \multirow{2}{*}{$\begin{array}{l}\text { Perbandingan } \\
\text { Tepung } \\
\text { Sorgum \& } \\
\text { Singkong }\end{array}$} & \multicolumn{3}{|c|}{ Konsentrasi GMS } \\
\hline & y1 $(0.6 \%)$ & y2 $(0.8 \%$ & y3 (1\%) \\
\hline $\begin{array}{c}\mathrm{x} 1 \\
(1: 8)\end{array}$ & $a 2.43^{\mathrm{A}}$ & $\begin{array}{l}3.46 \\
\mathrm{a}\end{array}$ & 3.79 \\
\hline $\begin{array}{c}x 2 \\
(1: 6)\end{array}$ & $\begin{array}{l} \\
\text { b } 3.91 \\
\end{array}$ & b 3.82 & $\begin{array}{l} \\
\\
\end{array}$ \\
\hline $\begin{array}{c}x 3 \\
(1: 5)\end{array}$ & $\begin{array}{l}\text { A } \\
\text { b } 3.81\end{array}$ & b 3.82 & $\begin{array}{ll} & A \\
& 3.72 \\
& \\
\end{array}$ \\
\hline
\end{tabular}

Keterangan : Setiap huruf yang berbeda menunjukan perbedaan yang nyata pada taraf $5 \%$. Huruf kapital dibaca horizontal dan huruf kecil dibaca vertical

Pada tanaman sorgum yang cenderung memiliki kandungan tannin yang tinggi selain memberikan efek pahit juga akan memberikan efek warna gelap pada produk sehingga dibutuhkan upaya pengurangan kadar tanin dengan penyosohan. Penyosohan sorgum dapat mengurangi kadar tanin hingga 75\% (Suarnia 2004). Sedangkan pada singkong efek penurunan pigmen setelah dilakukan proses pemanasan sangatlah sedikit dantidak memiliki pengaruh yang memnyebabkan sampel menjadi tidak menarik. Gilesrol monostearat memberikan efek yang signifikan terhadap kenampakan beras analog karena dapat memperbaiki penampilan produk yang rusak selama proses ekstruksi berlangsung.

\section{Penentuan Sampel Tepilih}

Sampel terpilih didapat dari hasil organoleptik pada produk beras analog. Penentuan sampel terbaik digunakan metode skoring, Penentuan sampel terbaik metode skoring ini gabungan dari metode statiska (Susetyo, 2010) dan metode skoring (Kartika, 1988). Metode statistika digunakan untuk membantu memudahkan dalam menentukan interval skor, sedangkan metode skoring digunakan untuk pemberian skor pada tiap- 
Perbandingan Tepung Sorgum dengan Tepung Singkong .. (Irfan Hadiyan, Wisnu Cahyadi dan Ina Siti Nurminabari)

tiap perlakuan. Selain itu, digunakan untuk mencari korelasi pengukuran subyektif dengan obyektif dalam rangka penentuan presisi pengukuran obyektif (Kartika, 1988).

Tabel 5. Penentuan Sampel Terpilih.

\begin{tabular}{|c|c|c|c|c|}
\hline \multirow{2}{*}{$\begin{array}{c}\text { Kode } \\
\text { sampel }\end{array}$} & \multicolumn{3}{|c|}{ Atribut } & Total \\
\cline { 2 - 4 } & Warna & Tekstur & Kenampakan & \\
\hline $\mathrm{x} 1 \mathrm{y} 1$ & 1 & 1 & 1 & 3 \\
\hline $\mathrm{x} 1 \mathrm{y} 2$ & 3 & 2 & 3 & 8 \\
\hline $\mathrm{x} 1 \mathrm{y} 3$ & 4 & 3 & 4 & 11 \\
\hline $\mathrm{x} 2 \mathrm{y} 1$ & 4 & 3 & 4 & 11 \\
\hline $\mathrm{x} 2 \mathrm{y} 2$ & 3 & 3 & 4 & 10 \\
\hline $\mathrm{x} 2 \mathrm{y} 3$ & 5 & 4 & 5 & 14 \\
\hline $\mathrm{x} 3 \mathrm{y} 1$ & 3 & 4 & 4 & 11 \\
\hline $\mathrm{x} 3 \mathrm{y} 2$ & 4 & 5 & 4 & 13 \\
\hline $\mathrm{x} 3 \mathrm{y} 3$ & 3 & 3 & 4 & 10 \\
\hline
\end{tabular}

\section{Respon Kimia}

\section{Kadar Air}

Analisis kadar air terhadap sampel beras analog fortifikasi dilakukan dengan metode gravimetri. Berdasarkan hasil analisis variasi (ANAVA) menunjukkan bahwa perbandingan tepung (X) dan konsentrasi GMS (Y) tidak berpengaruh terhadap kadar air dan tidak terjadi interaksi antara keduanya.

Tabel 6. Interaksi Antara Perbandingan Jenis Tepung dan Konsentrasi GMS Terhadap Kadar Air Beras Analog.

\begin{tabular}{|c|c|c|c|}
\hline \multirow{2}{*}{$\begin{array}{l}\text { Perbandingan } \\
\text { Tepung } \\
\text { Sorgum \& } \\
\text { Singkong }\end{array}$} & \multicolumn{3}{|c|}{ Konsentrasi GMS } \\
\hline & $\mathrm{y} 1(0.6 \%)$ & $\mathrm{y} 2(0.8 \%)$ & y3 (1\%) \\
\hline $\begin{array}{c}x 1 \\
(1: 8)\end{array}$ & $\mathrm{ab}^{\mathrm{A}}$ & $a^{\mathrm{A}}$ & $6.75^{\mathrm{A}}$ \\
\hline $\begin{array}{c}x 2 \\
(1: 6)\end{array}$ & $a^{4.99}{ }^{\mathrm{A}}$ & $\begin{array}{l}\text { B } \\
\text { b } 7.21^{-1}\end{array}$ & $a \quad .75^{\mathrm{A}}$ \\
\hline $\begin{array}{c}\text { x3 } \\
(1: 5)\end{array}$ & $b^{5.74}$ & $a^{\mathrm{A}}$ & $5 \begin{array}{l}\mathrm{AB} \\
\mathrm{a}\end{array}$ \\
\hline
\end{tabular}

Keterangan : Setiap huruf yang berbeda menunjukan perbedaan yang nyata pada taraf $5 \%$. Huruf kapital dibaca horizontal dan huruf kecil dibaca vertical

Kadar air pada beras analog fortifikasi lebih rendah daripada standar mutu kadar air untuk beras yang dipersyaratkan oleh Standar Nasional Indonesia (2008) yaitu maksimal $14 \%$, hal ini disebabkan proses pengeringan yang dilakukan pada beras analog hingga 22 jam dengan prinsip penguapan air pada beras analog, maka akan menurunkan kadar air.

\section{Kadar Abu}

Berdasarkan hasil analisis kadar abu terhadap beras analog maka didapat terhadap sampel $\mathrm{x} 2 \mathrm{y} 3$ didapat hasil $0,9250 \%$ dan sampel x3y2 didapat hasil $0,9780 \%$. Dari hasil analisis menunjukan bahwa kadar abu pada beras analog cukup rendah. Semakin tinggi konsentrasi gliserol monostearat yang ditambahkan, maka kadar abu beras analog semakin meningkat. Kadar abu pada beras analog yang dihasilkan cukup rendah. Oleh karena itu, dapat dilakukan pengembangan produk yang mengandung mineral tinggi untuk memenuhi zat gizi yang hilang selama pengolahan maupun dengan tujuan fortifikasi mineral tertentu

Pengabuan dilakukan untuk menentukan jumlah mineral yang terkandung dalam bahan. Penentuan kadar mineral bahan secara asli sangatlah sulit sehingga perlu dilakukan dengan menentukan sisa hasil pembakaran atas garam mineral bahan tersebut. Pengabuan dapat menyebabkan hilangnya bahan-bahan organik dan anorganik sehingga terjadi perubahan radikal organik dan segera terbentuk elemen logam dalam bentuk oksida atau bersenyawa dengan ion-ion negatif (Krisno.dkk, 2001).

\section{Protein}

Berdasarkan hasil analisis kadar protein terhadap beras analog maka didapat terhadap sampel $\mathrm{x} 2 \mathrm{y} 3$ didapat hasil 7,9163\% dan sampel x3y2 didapat hasil 7,8937\%. Dari hasil analisis protein terhadap beras analog dapat dilihat bahwa kedua sampel memiliki perbedaan kadar protein yang rendah 
dibawah 8\%. Hal ini juga menunjukkan bahwa perbandingan tepung singkong dengan tepung sorgum merah tidak memberikan pengaruh nyata terhadap kadar protein beras analog. Protein beras analog berasal dari protein tepung sorgum merah yang digunakan. Kadar protein dalam produk pangan juga dapat berpengaruh terhadak indeks glikemik. Kadar protein yang tinggi, cenderung nilai indeks glikemik yang lebih tinggi (Rimbawan, 2004).

\section{Lemak}

Berdasarkan hasil analisis kadar lemak terhadap beras analog maka didapat terhadap sampel $\mathrm{x} 2 \mathrm{y} 3$ didapat hasil $0,9777 \%$ dan sampel x3y2 didapat hasil 0,9407\%. Dari hasil analisis lemak terhadap beras analog dapat dilihat bahwa kedua sampel memiliki perbedaan kadar lemak yang rendah dan kandungan lemak beras analog yang rendah memiliki masa simpan yang lebih lama karena oksidasi lemak relatif rendah. Oksidasi dapat menyebabkan beras analog menjadi tengik sehingga umur simpan menjadi lebih singkat.

\section{Karbohidrat}

Berdasarkan hasil analisis kadar karbohidrat total terhadap beras analog maka didapat terhadap sampel $\mathrm{x} 2 \mathrm{y} 3$ didapat hasil $84,681 \%$ dan sampel x3y2 didapat hasil $84,2876 \%$. Dari hasil analisis karbohidrat total terhadap beras analog dapat dilihat bahwa kedua sampel memiliki perbedaan kadar karbohidrat yang sangat kecil. Kadar karbohidrat total pada beras analog termasuk tinggi karena bahan baku yang sebagian besar berasal dari tepung memiliki kadar karbohirat yang tinggi. Hal ini merupakan suatu keunggulan karena beras analog memiliki kadar karbohidrat yang lebih tinggi dibandingkan beras padi, beras analog dapat dijadikan sebagai alternatif sumber karbohidrat.

\section{Amilosa dan Amilopektin}

Berdasarkan hasil analisis pada sampel x2y3 didapat kadar pati 56,29\%; amilosa 18,37\%; dan amilopektin 37,92\%; sampel x3y2 didapat kadar pati 56,13\%; amilosa 18,40\%; dan amilopektin 37,73\%. Dari hasil analisis karbohidrat pati terhadap beras analog dapat dilihat bahwa kedua sampel memiliki perbedaan kadar karbohidrat yang sangat kecil. Kadar karbohidrat pati yang termasuk tinggi karena bahan baku yang sebagian besar berasal dari tepung memiliki kadar karbohirat yang tinggi. Dari hasil analisa amilosa dan amilopektin yang didapat, beras analog ini dapat dikategorikan beras analog merupakan beras yang pulen.

\section{Serat Kasar}

Berdasarkan hasil analisis serat terhadap sampel $\mathrm{x} 2 \mathrm{y} 3$ di dapat hasil $0,4892 \%$ dan sampel x3y2 0,3918\%. Dari hasil analisis serat terhadap beras analog dapat dilihat bahwa kedua sampel memiliki perbedaan kadar serat yang sangat kecil. Dalam produk beras analog terdapat bahan baku yang memiliki kadar serat yang tinngi yaitu dari sorgum, kadar serat kasar yang terkandung dalam tepung sorgum $4.5 \%$. hal ini disebabkan karena adanya kandungan lembaga dan aleuron yang terbawa endosperm karena proses penyosohan biji yang tidak sempurna (Hermawan, 2014).

\section{Zat Besi dan Iodium}

Dari hasil analisis menunjukkan bahwa terjadi peningkatan kadar Fe sekitar $21 \%$ pada beras analog dan kadar KIO3 pada bahan turun sekitar $80 \%$. Kehilangan kadar iodium ini disebabkan karena sifat iodium, yaitu iodium mudah larut dalam air, mudah menguap, serta mudah rusak bila terkena cahaya atau panas (Yogaswara, 2008).

Tabel 7. Pengaruh Bahan Fortifikan Fe Fumarat dan KIO3 Terhadap Karakteristik Beras Analog

\begin{tabular}{|c|c|c|c|c|}
\hline \multirow{3}{*}{ Sampel } & \multicolumn{4}{|c|}{ Fortifikan } \\
\cline { 2 - 5 } & \multicolumn{2}{|c|}{ Fe Fumarat } & \multicolumn{2}{c|}{ KIO3 } \\
\cline { 2 - 5 } & Kadar & Kadar & Kadar & Kadar \\
& Awal & Akhir & Awal & Akhir \\
\hline x2y3 & 57.56 & 69.24 & 185.45 & 9.57 \\
& ppm & ppm & ppm & ppm \\
\hline x3y2 & 57.56 & 69.24 & 185.45 & 34.62 \\
& ppm & ppm & ppm & ppm \\
\hline
\end{tabular}




\section{Respon Mikrobiologi}

\section{Angka Lempeng Total (TPC)}

Berdasarkan hasil analisis TPC terhadap sampel beras analog maka didapat hasil pada sampel x2y3 $6.0 \times 10^{1} \mathrm{cfu} / \mathrm{g}$ dan sampel $\mathrm{x} 3 \mathrm{y} 24.0 \times 10^{1}$. Dari hasil analisis angka lempeng total (TPC) menunjukkan adanya jumlah koloni dari mikroba yang beragam dari setiap sampel dan ulangan. Hal ini disebabkan oleh adanya kontaminasi silang selama pencampuran bahan maupun pada saat proses pengolahan yang berassal dari lingkungan sekitar maupun dari peneliti selama kegiaatan penelitian berlangsung.

\section{E. Coli}

Dari hasil analisis terhadap bakteri coliform menunjukkan hasil 0 , hal ini dapat didefinisikan bahwa selama proses pengolahan berlangsung baik dari bahan baku, alat, dan lingkungan tidak terdapat suatu kondisi yang memungkinkan adanya cemaran bakteri coliform.

\section{Respon Fisik}

\section{Pengukuran Dimensi}

Dari hasil pengukuran didapat 4,5 x 2 $\mathrm{mm}$ bahwa ukuran beras analog hampir mendekati dengan beras umum dipasaran contohnya IR-64 dengan rata-rata ukuran $5 \mathrm{x}$ $1.5 \mathrm{~mm}$, sehingga secara visual beras analog masih bisa diterima oleh masyarakat. Ukuran beras analog yang beragam dapat disebabkan oleh tidak adanya penekanan kepada dies ekstruder yang konstan selama proses pembuatan.

\section{Bobot 1000 Butir}

Dari hasil penelitian didapat rata-rata 17,9 gram yang menunjukkan bahwa jika dibandingkan dengan beras IR-64 dengan rata-rata bobot 1000 butir adalah 19 gram beras analog dalam penelitian ini sebagian besar lebih rendah dengan beras sosoh. Hal ini dapat disebabkan ukuran beras analog yang lebih kecil dibandingkan beras sosoh. Bobot per butir beras analog dapat dipengaruhi oleh proses pencetakkan beras analog menggunakan ekstruder.

\section{Densitas Kamba}

Dari hasil pengukuran didapat ratarata $0,690 \mathrm{~g} / \mathrm{ml}$ jika dibandingkan dengan beras sosoh IR-64 yang memiliki densitas kamba $0.790 \mathrm{~g} / \mathrm{ml}$ memiliki densitas kamba yang lebih rendah. Sehingga dapat disimpulkan beras analog memiliki berat yang lebih kecil dibandingkan beras padi yang disosoh pada volume yang sama. Densitas kamba beras analog yang rendah juga menunjukkan beras analog memiliki porositas yang tinggi.

\section{KESIMPULAN}

1. Berdasarkan penelitian pendahuluan analisis kimia diketahui tepung sorgum merah memiliki kadar air 10,3\%, lemak $0,5 \%$, protein $10,2 \%$, dan karbohidrat pati 70,91\%. Tepung singkong kadar air $14,5 \%$, lemak $0,7 \%$, protein $1,5 \%$, dan karbohidrat pati $81,3 \%$.

2. Perbandingan tepung sorgum merah dan tepung singkong berpengaruh terhadap respon organoleptik warna, tekstur, dan kenampakan dan tidak berpengaruh terhadap respon kimia kadar air.

3. Konsentrasi gliserol monostearat (GMS) berpengaruh terhadap respon organoleptik warna, tekstur, dan kenampakan dan tidak berpengaruh terhadap respon kimia kadar air.

4. Hasil interaksi antara perbandingan jenis tepung dan konsentrasi gliserol monostearat (GMS) berpengaruh terhadap respon organoleptik warna, tekstur, dan kenampakan dan tidak berpengaruh terhadap respon kimia kadar air.

5. Hasil fortifikasi yang dilakukan terhadap beras analog dengan fortifikan $\mathrm{Fe}$ mengalami peningkatan kadar sebanyak $21 \%$ dan fortifikan KIO3 mengalami penuruan sebanyak $80 \%$. Hal tersebut diakibatkan karena pengaruh penggunaan alat, penggunaan suhu yang tinggi, dan karakteristik bahan fortifikasi 
Perbandingan Tepung Sorgum dengan Tepung Singkong .. (Irfan Hadiyan, Wisnu Cahyadi dan Ina Siti Nurminabari)

sehingga terjadi perubahan mutu bahan fortifikan.

6. Hasil analisis fisik menujukkan bahwa, jika dilihat dari segi dimensi, densitas kamba, dan bobot 1000 butir beras analog dalam penelitian ini masih layak jika dibandingkan dengan beras sosoh IR-64.

\section{DAFTAR PUSTAKA}

Budijianto, et al. (2011). Metode Pembuatan Beras Analog. Bogor: Isntitut Pertanian Bogor.

Hermawan, S. 2014. Budidaya dan Pemanfaatan Tanaman Sorgum Varietas Putih. Malang. Universitas Brawijaya.

Martianto, D., Briawan, D., Ariani, M., dan Yulianis, M. 2009. Percepatan Diversifikasi Konsumsi Pangan Berbasis Pangan Lokal : Perspektif Pejabat Daerah dan Strategi Pencapaiannya. Jurnal Gizi dan Pangan, Vol. 4 No. 3 :123-131

Martianto, et al. (2009). Pengkajian Diversifikasi Pangan Di Indonesia Pada Tahun 2010. Bogor: Isntitut Pertanian Bogor.

Mishra, et al. (2012). Teknologi Ekstruksi Dalam Pembuatan Beras Analog. Bogor: Isntitut Pertanian Bogor.

Samad, MY. 2003. Pembuatan Beras Tiruan (Artificial Rice) Dengan Bahan Baku Ubi Kayu dan Sagu. J Saint dan Teknologi BPPT VII.IB.02

Suarnib. 2006. Pemanfaatan Tepung Sorgum untuk Produk Olahan. Jurnal Litbang Pertanian 23(4) 2006.
Winarno, F.G. 1997. Kimia Pangan dan Gizi. PT. Gramedia, Jakarta.

Yoshida, T., Sagara, T., Ojima, T., Takahashi, R., dan Takahashi, M. 1971. Process For Producing Artificial Rice. USA 3620762. 